\title{
UPAYA DALAM MEMBINA PROFESIONAL GURU MELALUI \\ SUPERVISI KUNJUNGAN KELAS
}

\author{
Meutya Kemala Safira
}

Gmail: meutyasafira04@gmail.com

\begin{abstract}
ABSTRAK
Proses pembelajaran dalam sebuah kelas, siswa dianggap telah belajar apabila tujuan pembelajaran yang telah dirumuskan telah berhasil dikuasi oleh siswa di dalam kelas. Peran guru sangat besar dalam sebuah kelas karena guru berperan sebagai penanggung jawab dan sebagai pengelola dalam proses pembelajaran di kelas. Guru harus memiliki profesionalitas dalam mengajar agar peserta didik didalamnya mengetahui apa yang guru sampaikan serta pemahaman dapat diterima oleh peserta didik. Membina profesionalitas guru dapat melalui supervisi yang merupakan kegiatan pembinan yang dilakukan kepala sekolah kepada guru untuk membantu memperbaiki situasi pembelajaran agar para siswa dapat belajar lebih efektif dengan prestasi belajar yang meningkat. Kinerja guru adalah hasil dari yang dikerjakannya sesuai dengan tuntutan profesi yang dimiliki yang dapat ditunjukkan dengan produktivitas kerja yang tinggi agar siswa yang diajarkannya agan mengalami peningkatan dalam belajar.
\end{abstract}

Kata kunci: Supervisi kunjungan kelas, Produktivitas Guru, Profesi Guru

\section{LATAR BELAKANG}

Guru adalah salah satu komponen sumber daya pendidikan memang penting untuk melakukan supervisi selain meningkatkan akademiknya maupun perbaikan terhadap kinerjanya demi mengingkatkan mutu siswa yang diajarnya. Guru di tuntut perlu memiliki profesional yang berdaya guna bagi siswa dalam belajar, karena dengan profesionalnya ini bisa membuat siswa memahami pengetahuan yang diberikan guru. Guru berperan mencciptakan kondisi pembelajaran dalam kelas yang efektif dan efesien. Kompetensi yang dimiliki guru tanpa menggunakan profesionalitas yang penting dalam belajar akan menjadikan siswa lambat memahami pembelajaran dari guru tersebut.

Supervisi yang memiliki peran dalam membina profesional guru demi terwujudnya peningkatkan kualitas belajar perserta didik dan pemahaman guru tentang konsep, teknik, dan metode belajar guru. Profesional guru adalah suatu tingkat penampilan seseorang dalam melaksanakan pekerjaan sebagai guru atau 
tenaga pendidik yang didukung dengan keterampilan yang dimiliki, kompetensi, kode etik dan pemahaman seorang guru.

Supervisi juga memiliki fungsi sebagai evalusi, untuk mengetahui kemampuan guru yang akan dibina, maka sebelumnya perlu dilakukan evaluasi sehingga program untuk meningkatkan profesionalitas guru berjalan sesuai dengan supervisi yang akan dilakukan sehingga terjadi suatu hubungan yang berkesinambungan antara yang akan disupervisi dan proses supervisi. Supervisor haruslah menjaga agar setiap guru dalam melaksanakan dan menjalankan tugasnya dengan baik dalam situasi kerja yang kooperatif.

Ciri-ciri yang dimiliki oleh seorang guru yang memiliki suatu sifat profesional adalah seorang guru yang profesional harus menguasai bidang ilmu pengetahuan yang diajarkannya kepada peserta didik yang akan menerimanya, seorang guru yang profesional harus memiliki kemampuan menyampaikan atau mengajarkan ilmu yangdimilikinya kepada peserta didik secara efektif dan efesien, seorang guru yang profesional harus berpegang teguh kode etik profesional profesional. Seorang guru harus memiliki intelegensi dan interest yang kuat untuk melaksanakan tugasnya dan pekerjaannya sesuai deng syarat-syarat profesionalitas yang yang telah disyaratkan diatas.

Didalam supervisi yang memiliki beberapa sumber ide, sumber informasi dan sumber petunjuk bagi permasalahan yang dihadapi guru salah satunya masalah peningkatan profesionalitas guru ini. Masalah profesionalitas guru dapat diketahui melalui kegiatan supevisi sehingga seorang supervisor dapat mengetahui tingkat profesionalitas seorang guru. Bagaimana ia dalam mengajar serta apa kekuarangannya, dan tingkat kemampuannya dalam menyusun kerangka pembelajaran.

Berdasarkan uraian diatas, permasalahan dalam tulisan ini adalah (1) bagaimana upaya yang dilakukan supervisi dalam membina profesionalitas guru? (2) bagaimana hubungan profesi guru dengan supervisi? Tujuan tulisan ini adalah untuk mengetahui cara-cara yang dapat dilakukan dalam upaya membina profesionalisme guru melalui supervisi pendidikan ? mengetahui bagaimana hubungan profesi guru dengan supervise?

\section{PEMBAHASAN}

(Prabowo, 2016) menyatakan bahwa : supervisi merupakan kegiatan pembimbingan yang bersifat manusiawi melalui hubungan yang demokratis, keterbukaan dan persahabatan. Yang termasuk fungsi utama dari supervisi ini adalah yaitu sebagai berikut :

1. Supervisi tidak dapat dipisahakan dengan administrasi karena keduanya memiliki koordinasi yang sangat kuat dan sama-sama saling menunjang dalam sistem pendidikan. 
2. Supervisi dapat mengkoordinasi personalia sekolah terutama para guru-gur disekolah serta aktivitas belajar disekolah agar meminimalisir terjadinya suatu penyimpangan

3. Supervisi dapat memperlancar proses belajar mengajar dengan memperhatikan beberapa segi instruksional. Salah satunya yaitu model belajar yang digunakan.

4. Mengendalikns usaha mendidik para siswa agar siswa dapat berkembang secara total, serta aspek individu yang dapat berkembang secara afeksi, kognisi dan psikomotor.

5. Memberikan bantuan pemikiran guru dalm bimbingan karir bagi siswanya agar dapat menyesuaikan dengan bakat, tingkat kemampuan dan minatnya.

Langkah-langkah supervisi kunjungan kelas (a) Perencanaan yang meliputi perancangan kegiatan supervisi yang akan dilakuka (b) Menentukan instrumen dalam melakukan observasi kesekolah (c)Mencari tahu dengan jalan observasi untuk mengetahui kesulitras-kesulitan yang dialami oleh guru dan oleh siswa dalam proses pembelajaran.

\section{Bagaimana upaya yang dilakukan supervisi dalam membina profesionalitas guru?}

Untuk mengembangkan suatu bidang pekerjaan yaitunya bidang pendidikan terutama khusunya dibutuhkan suatu profesionalitas seorang guru. Kemampuan, ientelegensi, keterampilan serta kecakapan dia dalam mengajar membutuhkan skill khusus, apabila terdapat suatu kekeliruaan dalam belajar makan dapat digunakan supervisi untuk memperbaiki kesalahn yang dialamai guru salah satunya peningkatan profesionalitas guru. Guru merupakan sumber daya utama didalam suatu kelas yang menjadi sorot uatama murid.

Jadi, guru dituntut bisa mengajar peserta didiknya secara maksimal. Apalagi pada saat sekarang ini perkembangan ilmu pengetahuan begitu cepat sehingga hal ini memicu guru gara dapat terus meningkatkan kemammpuan dan keterampilannya. Supervisi inilah yang dapat berperan sebagai pembinaan profesionalitas guru karena salah satu dari fungsi supervisi pendidikan sendiri yaitunya memberikan bantuan pemikiran kepada guru dengan bimbingan yang dilakukan kepada guru agar guru bisa mengetahui kesalahan yang dia miliki dan memperbaikinya.

Supervisor memegang peranan penting dalam meningkatkan kualitas guru agar dapat melaksanakan pembelajaran yang lebih berkualitas.Jabatan supervisor di sekolah meliputi kepala sekolah dan pengawas. Supervisi yang dilakukan oleh kepala sekolah diatur dalam Permen Diknas Nomor 13 Tahun 2007 tentang standar Kepala Sekolah/Madrasah. Kata kunci : supervisi pendidikan, pengembangan keprofesionalitas guru berkelanjutan. (A. Sabandi, 2013) 


\section{PENUTUP}

Kesimpulan

Berdasarkan pembahasan di atas disimpulkan bahwa siswa yang seharusnya mendapat pengetahuan pengajaran dari guru belum $100 \%$ memahami apa yang disampaikan guru, dan dikhawatirkan dapat menurunkan prestasi belajar siswa, guru sebagai fasilitator harus dibekali dengan peningkatan profesionalitas demi terwujudnya pembelajaran yang dapat dimengerti oleh seluruh siswa. Karena pemahaman siswa tergantung pada penjelasan dari gurunya. Guru perlu melakukan intropeksi diri dan pendekatan kepada siswa apa kekurangan yang ia miliki agar ia mampu memperbaiki cara mengajarnya dan dapat meningkatkan keprofesionalitasannya.

\section{Saran}

Dengan adanya peningkatan profesionalitas guru disekolah diharapkan untuk semua sekolah perlu juga memiliki supervise dimasing-masing sekolah, jika sekolah menginginkan peningkatan belajar pada siswanya sekolah perlu menyediakan supervise disekolahnya demi terciptanya tujuan pendidikan yang diinginkaan. Perlu dilihat apakah kinerja guru telah memnuhi syarat atau tidak jika tidak maka bisa dilakukan perbaikan pada kinerja guru tersebut.

\section{REFERENSI}

A. Sabandi. (2013). SUPERVISI PENDIDIKAN UNTUK PENGEMBANGAN PROFESIONALITAS GURU BERKELANJUTAN. Pedagogi, Jurnal Ilmiah Ilmu Pendidikan, XIII(2), 1-9. Retrieved from http://ejournal.unp.ac.id/index.php/pedagogi/article/view/4275/3345

Prabowo, S. dk. (2016). SUPERVISI KUNJUNGAN KELAS SEBAGAI UPAYA MEMBINA PROFESIONAL GURU SLTP/SLTA. Sosial Humaniora, 9(1), 1-18. Retrieved from http://id.portalgaruda.org/index.php?ref=browse \&mod=viewarticle\&article= 453140 